\title{
Meningkatkan Hasil Belajar Matematika melalui Model Pembelajaran Numbered Head Together (NHT) Pada Siswa Sekolah Dasar
}

\author{
Erma Hening Hastuti ${ }^{1}$, Samrin ${ }^{2}$, Raehang ${ }^{3}$ \\ ${ }^{1}$ Institut Agama Islam Negeri Kendari \\ ${ }^{2}$ Institut Agama Islam Negeri Kendari, Indonesia. E-mail: samrinsam75@yahoo.com \\ ${ }^{3}$ Institut Agama Islam Negeri Kendari, Indonesia. E-mail: asyrafraehang @gmail.com
}

\section{Articel info \\ Artikel history: \\ Received: 4 April 2020 \\ Revised: 18 April 2019 \\ Accepted: 18 April 2020}

DOI:
Abstract
The objective of this research was to investigate mathematic's learning outcome throught the implementation of numbered head together (HNT) in learning activities. This is an action class research with Kemmis \&Mc Taggart model. The sucject of this study was fourth-grade students of elementary school 3 Tinanggea with 11 man and 12 women. The data of the research were gained throght observation, and test then were converted into qualitative and quantitave analysis. Based the observation, both teacher and student activities showed an improvement in each cycle with $3.71 \%$ in cycle one raising to $11.11 \%$ in cycle two for teacher activites, while for student activities $7.41 \%$ in cycle one raising to $14.82 \%$ in cycle two. Besides, learning outcome experienced an increasing percentage with $73.70 \%$ in cycle one and $84.78 \%$ in cycle two. The completeness rate of the learning activities was $60.86 \%$ in the first meeting while $78.26 \%$ was in the second meeting.

Keywords: Numbered Head Together (NHT) learning model, mathematic learning outcome
Informasi Artikel

Riwayat Artikel:

Diterima: 4 April 2020

Direvisi: 18 April 2020

Accepted: 18 April 2020

\section{Abstrak}

Penelitian ini bertujuan untuk mengetahui hasil belajar matematika melalui model pembelajaran Numbered Head Together (NHT) pada siswa kelas IV SDN 3 Tinanggea. Jenis penelitian ini adalah penelitian tindakan kelas (PTK). Desain Penelitian mengguakan model Kemmis \&Mc Taggart. Subjek penelitian ini adalah siswa kelas IV SDN 3 Tinanggea yaitu 11 siswa laki-laki dan 12 siswa perempuan. Data-data dalam penelitian ini diperoleh melalui observasi dan hasil belajar yang dianalisis secara kualitatif dan kuantitatif. Berdasarkan hasil observasi diketahui bahwa aktivitas guru dan siswa mengalami peningkatan dari setiap siklus. Hal ini dapat dilihat dari persentase aktivitas guru dari siklus 1 ke siklus II 
yaitu 11,11\% menjadi 3,71\%. Sedangkan persentase aktivitas siswa mengalami peningkatan dari siklus I ke siklus II yaitu 14,82\% menjadi 7,41\%. Hasil penelitian menunjukkan bahwa rata-rata hasil belajar pra siklus sebesar 60,65, siklus I sebesar 73,70 dan pada siklus II sebesar 84,78. Tingkat ketuntasan pada pra siklus adalah 34,78\%, pada siklus I menjadi 60,86\% dan pada siklus II menjadi 78,26\%. Adapun persentase peningkatan dari pra siklus ke siklus I adalah $21,51 \%$ sedangkan persentase peningkatan dari siklus I ke siklus II adalah 15,03\% dan persentase peningkatan dari pra siklus ke siklus II adalah 39,78\%.

DOI:

Kata Kunci: Pembelajaran Numbered Head Together (NHT), Hasil

Belajar Matematika

\section{PENDAHULUAN}

Pendidikan pada dasarnya dilaksanakan untuk meningkatkan kehidupan bangsa yang bermutu baik, sebagaimana yang disebutkan dalam Undang-undang No. 20 tahun 2003 tentang Sintem Pendidikan Nasional Bab I Pasal I (ayat I) yang menjelaskan bahwa: "Pendidikan adalah usaha sadar dan terencana untuk mewujudkan suasana belajar dan proses pembelajaran agar peserta didik secara aktif mengembangkan potensi dirinya untuk memiliki kekuatan spiritual keagamaan, pengendalian diri, kepribadian, kecerdasan, akhlak mulia, serta keterampilan yang diperlukan dirinya, masyarakat, bangsa dan negara". (UU RI No. 20 Tahun 2003, Tentang Sistem Pendidikan Nasional (SISDIKNAS), 2003).

Pelajaran matematika merupakan salah satu pelajaran yang diajarkan pada jenjang sekolah dasar. Berkaitan dengan hal tersebut, Daryanto menyatakan bahwa "Mata pelajaran matematika perlu diberikan kepada semua peserta didik mulai dari sekolah dasar untuk membekali mereka dengan kemampuan berpikir logis, analitis, sistematis, kritis dan kreatif serta kemampuan bekerja sama". (Daryanto, 2012). Belajar matematika merupakan suatu syarat cukup untuk melanjutkan pendidikan ke jenjang berikutnya, Karena dengan belajar matematika, kita akan belajar bernalar secara kritis, kreatif dan aktif". ( Ahmad Susanto, 2013). Menurut Dimyati dan Mudjiono mengemukakan bahwa: Hasil belajar merupakan hasil dari suatu interaksi tindak belajar dan tindak mengajar. Dari sisi guru, tindak mengajar diakhiri dengan proses evaluasi hasil belajar. Dari sisi siswa, hasil belajar merupakan berakhirnya penggal dan puncak proses belajar. ( Dimyati \& Mudjiono, 2013).

Hasil observasi awal di SDN 3 Tinanggea Kabupaten Konawe Selatan khususnya kelas IV dalam proses pembelajaran Matematika, guru masih kurang menerapkan model pembelajaran aktif, inovatif dan menyenangkan dalam proses pembelajaran. sehingga pada saat proses pembelajaran berlangsung masih ditemukan siswa yang tengah mengantuk terutama siswa yang duduk dibarisan paling belakang, mengerjakan tugas lain, bermain, mengobrol dengan temannya, keluar masuk dalam ruangan, dan berceloteh sendiri. Peneliti juga menemukan bahwa siswa sangat pasif sekali dan merasa enggan bila dimintai oleh guru untuk maju ke depan mengerjakan tugas yang telah diberikan. Selain itu, guru belum menerapkan model pembelajaran yang bervariasi yang tepat untuk membantu kesulitan belajar siswa, sehingga memperkuat anggapan siswa bahwa matematika itu sulit. Kondisi seperti ini mengakibatkan kurangnya perhatian dan aktivitas siswa dalam pembelajaran sehingga dapat mengakibatkan rendahnya daya serap siswa terhadap materi yang diajarkan dan dapat mempengaruhi hasil belajar yang belum sesuai dengan KKM yang diharapkan.

Data dokumentasi nilai ulangan harian pada mata pelajaran matematika siswa kelas IV SDN 3 Tinanggea pada semester 1 tahun pelajaran 2017/2018 masih di bawah kriteria ketuntasan minimal (KKM) yang ditetapkan oleh sekolah yaitu 65. Data hasil belajar ditunjukkan dengan nilai terendah 45 dan nilai tertinggi 75 dari 23 siswa. Yang mencapai KKM hanya 8 siswa $(34,78 \%)$ sedangkan yang belum mencapai KKM ada 15 siswa $(65,21 \%)$. Dengan data tersebut maka dapat disimpulkan bahwa hasil pembelajaran matematika masih belum optimal. Maka dipandang perlu untuk mengadakan pembaharuan belajar dalam proses pembelajaran untuk mengatasi permasalahan di atas, karena apabila terus dibiarkan akan berdampak buruk pada kualitas pembelajaran. 
Salah satu cara meningkatkan hasil belajar siswa hingga tercapainya nilai KKM yaitu dengan menerapkan berbagai model pembelajaran aktif, salah satunya adalah menerapkan model pembelajaran Numbered Head Together (NHT) di kelas. Femmy Kawuwung menyatakan bahwa Model pembelajaran Numbered Head Together (NHT) merupakan suatu model pembelajaran dengan cara setiap peserta didik diberi nomor, kemudian dibuat suatu kelompok selanjutnya guru memanggil nomor peserta didik sebagai ganti pertanyaan langsung kepada seluruh kelas.

Model pembelajaran Numbered Head Together (NHT) mengedepankan aktivitas peserta didik dalam mencari, mengolah, dan melaporkan informasi dari beberapa sumber belajar yang akhirnya untuk dipresentasikan di depan kelas (Femmy Kawuwung, 2011). Menurut Warsono dan Hariyanto bahwa aktivitas yang dilakukan dalam model pembelajaran NHT ini dapat mendorong siswa untuk berfikir dalam satu tim dan berani tampil mandiri. (Warsono \& Hariyanto, 2012).

Model NHT memiliki beberapa kelebihan dan kekurangan. Dimana menurut Hamdayama Jumanta kelebihan NHT yaitu: a) Melatih siswa untuk dapat bekerja sama dan menghargai pendapat orang lain, b) Melatih siswa untuk bisa jadi tutor sebaya, c) Memupuk rasa kebersamaan, d) Membuat siswa terbiasa dengan perbedaan. Sedangkan kekurangannya yaitu: a) Siswa yang terbiasa dengan cara konvensional akan sedikit kewalahan, b) Guru harus bisa memfasilitasi siswa, c) tidak semua mendapat giliran. (Hamdayama Jumanta, 2014).

Alasan peneliti menerapkan model pembelajaran Numbered Head Together (NHT) yaitu diharapkan bisa memberikan motivasi bagi siswa untuk tetap semangat dalam mengikuti proses pembelajaran, dapat meningkatkan kemampuan siswa dalam memahami materi pelajaran, menumbuhkan sikap menerima kekurangan diri dan orang lain serta memberikan kesempatan kepada siswa untuk menuangkan ide yang dia pikirkan. Siswa tidak hanya berdiam diri, akan tetapi ikut aktif dalam kegiatan pembelajaran.

\section{METODE}

Jenis penelitian ini adalah Penelitian Tindakan Kelas (Classroom action Research) atau yang sering disingkat PTK. Menurut Kusnandar sebagaimana yang dikutip oleh Ekawarna menjelaskan bahwa PTK adalah suatu kegiatan yang dilakukan oleh guru atau bersama-sama orang lain (kolaborasi) yang bertujuan untuk memperbaiki dan meningkatkan mutu proses pembelajaran di kelas. (Ekawarna, 2009). Penelitian ini dilaksanakan di kelas IV SDN 3 Tinanggea. Adapun yang menjadi alasan peneliti mengapa mengambil subjek penelitian ini di kelas IV bukan di kelas lain yaitu: pertama, kurangnya keaktifan siswa dalam menerima pembelajaran baik dalam memberikan tanggapan ketika guru memberikan pertanyaan atau soal diskusi. Kedua, kurang terciptanya suasana gembira dalam proses pembelajaran, hal ini mengakibatkan siswa cenderung bosan, sehingga sebagian dari siswa ada yang mengantuk, melamun dan sering keluar masuk ke dalam ruangan. Ketiga, rendahnya hasil belajar siswa pada mata pelajaran matematika yang ditandai dengan nilai rata-rata siswa yang belum mencapai KKM.

Penelitian ini dilaksanakan pada semester genap (Semester II) tahun ajaran 2018/2019 Selatan selama tiga bulan yaitu pada bulan Februari sampai bulan April tahun 2019. Tindakan pembelajaran dilakukan melalui 2 siklus. Subjek penelitian dalam penelitian ini adalah siswa kelas IV SDN 3 Tinanggea yang berjumlah 23 siswa yang terdiri dari 11 siswa laki-laki dan 12 siswa perempuan. Adapun yang akan diteliti antara lain: Faktor guru, faktor siswa dan efektifitas pembelajaran. Desain penelitian ini terdiri dari empat kegiatan yang dilakukan disetiap siklusnya. Empat kegiatan utama yang ada pada setiap siklus yaitu : 1) Perencanaan, 2) pelaksanaan, 3) Pengamatan, 4) Refleksi. (Suharsimi Arikunto, 2010). Tehnik pengumpulan data dalam penelitian ini terdiri dari observasi, wawancara, tes hasil belajar dan dokumentasi.

\section{HASIL PENELITIAN}

Sekolah Dasar Negeri 3 Tinanggea yang menjadi lokasi peneliti terletak di Jln. Poros Lapoa-Bombana/ Desa Lapoa kec. Tinanggea, kab. Konawe Selatan Provinsi Sulawesi Tenggara. Sekolah ini berdiri sejak tahun 1985 dengan nama SDN 1 Lapoa yang kemudian berubah nama sejak tahun 2013 
menjadi SDN 3 Tinanggea, dengan status kepemilikan/Daerah yang memiliki akreditas C, yang di pimpin oleh bapak Sarman, S.Pd.

Penelitian ini dilaksanakan dalam dua siklus. Setiap siklus terdiri dari dua kali pertemuan. Pelaksanaannya disesuaikan dengan prosedur penelitian yang telah ditentukan sesuai dengan kurikulum di sekolah dan sesuai dengan rencana pelaksanaan model pembelajaran Numbered Head Together (NHT). Dimana langkah-langkah dari model NHT yaitu: 1) Siswa dibagi dalam kelompok, setiap siswa dalam setiap kelompok mendapat nomor, 2) Guru memberikan tugas dan masing-masing kelompok mengerjakannya, 3) kelompok mendiskusikan jawaban yang benar dan memastikan tiap anggota kelompok dapat mengerjakan/ mengetahui jawabannya, 4) Guru memanggil salah satu nomor siswa dengan nomor yang dipanggil melaporkan kerja sama mereka, 5) Tanggapan dari teman yang lain, kemudian guru menunjuk nomor yang lain, 6) Kesimpulan. ( Zainal Aqib, 2013). Pendapat lain mengenai langkah-langkah NHT menurut Kurniasih dan Berlin meliputi: a) Membentuk secara heterogen, b) Setiap kelompok beranggotakan 3-5 orang, c) Setiap anggota memiliki satu nomor, d) Guru mengajukan pertanyaan untuk didiskusikan bersama kelompok, e) salah satu nomor dapat mewakili kelompok untuk mempresentasikan hasil diskusi. ( Imas dan Berlin, 2015).

Proses tindakan dalam penelitian ini terdiri dari dua siklus yang terdiri dari perencanaan, pelaksanaan tindakan, observasi, evaluasi dan refleksi. Berdasarkan hasil penelitian yang telah dilaksanakan hasil observasi aktivitas guru dilakukan melalui pengamatan langsung oleh kolaborator dari siklus I dan siklus II dapat dilihat pada grafik di bawah ini.

Kemampuan guru dalam mengelola pembelajaran dengan menggunakan model NHT telah mengalami peningkatan dari setiap siklusnya. Dari gambar I tersebut dapat disimpulkan persentase aktivitas guru siklus I pertemuan pertama sebesar 70,37\% dan pertemuan kedua mencapai 81,48\%. Pada siklus II pertemuan pertama meningkat menjadi 96,29\% sedangkan pada pertemuan kedua mengalami peningkatan menjadi $100 \%$.

Dalam Proses pembelajaran aktivitas siswa telah mengalami peningkatan dari setiap siklus dengan menggunakan model NHT. Sehingga dari gambar 2 tersebut dapat diketahui bahwa hasil aktivitas siswa pada siklus I pertemuan pertama mencapai 66,66\% sedangkan pertemuan kedua mencapai $81,48 \%$. Pada siklus II pertemuan pertama meningkat menjadi $92,59 \%$ dan pada pertemuan kedua meningkat sebesar $100 \%$.

Berdasarkan hasil penelitian yang telah dilaksanakan oleh peneliti di kelas IV SDN 3 Tinanggea, menujukkan bahwa hasil belajar yang diperoleh oleh siswa dari pra siklus, siklus I dan siklus II dapat dilihat bada grafik pada gambar 3.: 


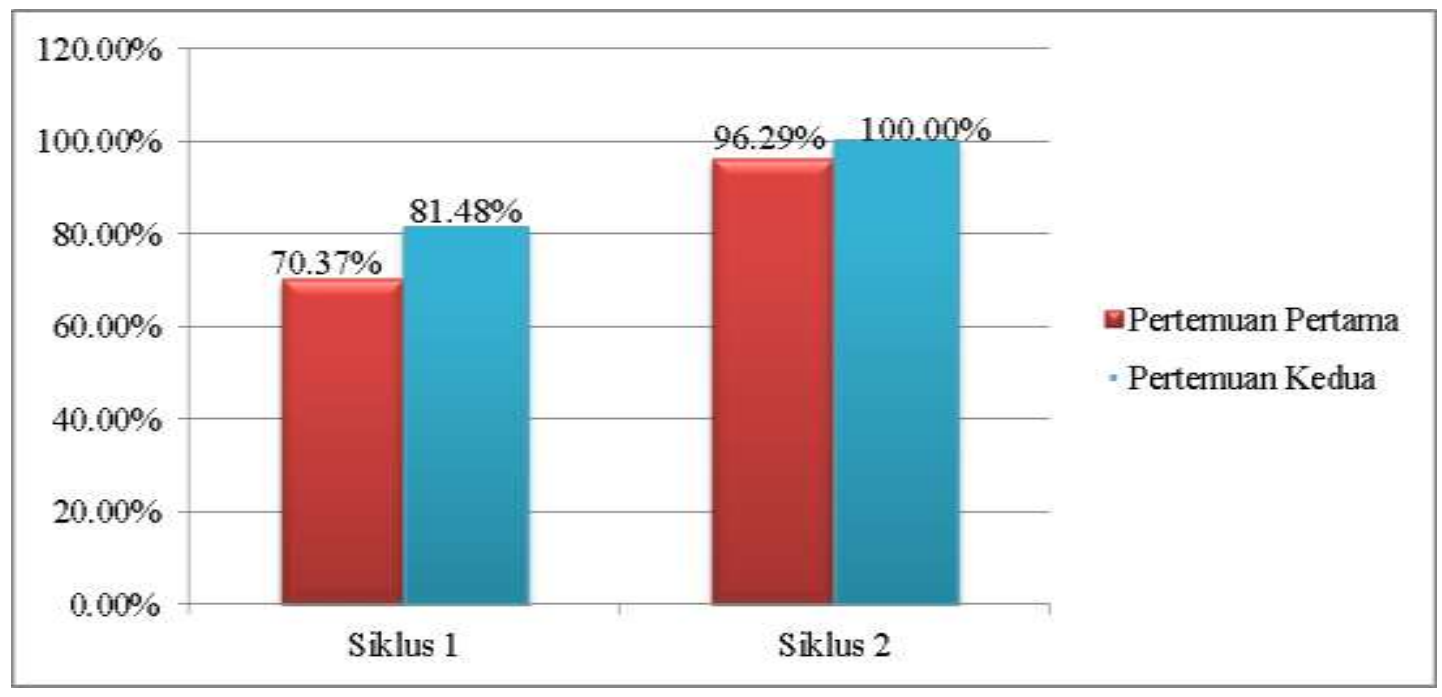

Gambar 1: Hasil Pengolahan Aktivitas Guru Pada Siklus I dan Siklus II

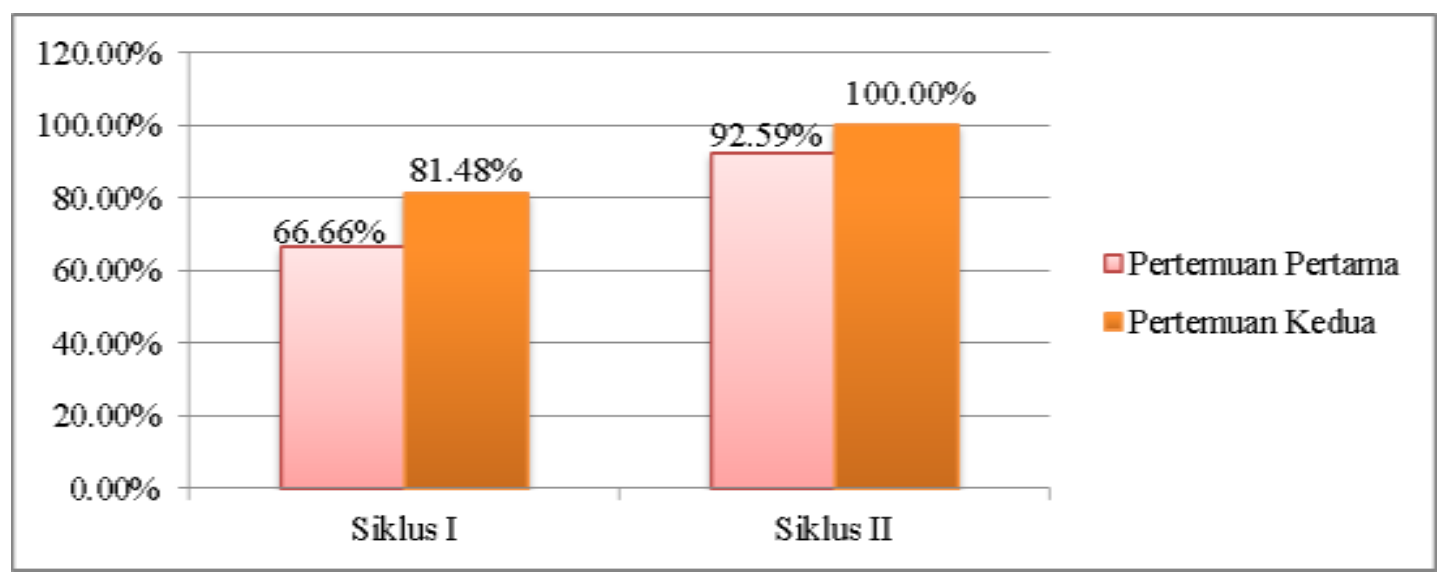

Gambar 2: Hasil Pengolahan Aktivitas Siswa pada Siklus I dan Siklus II

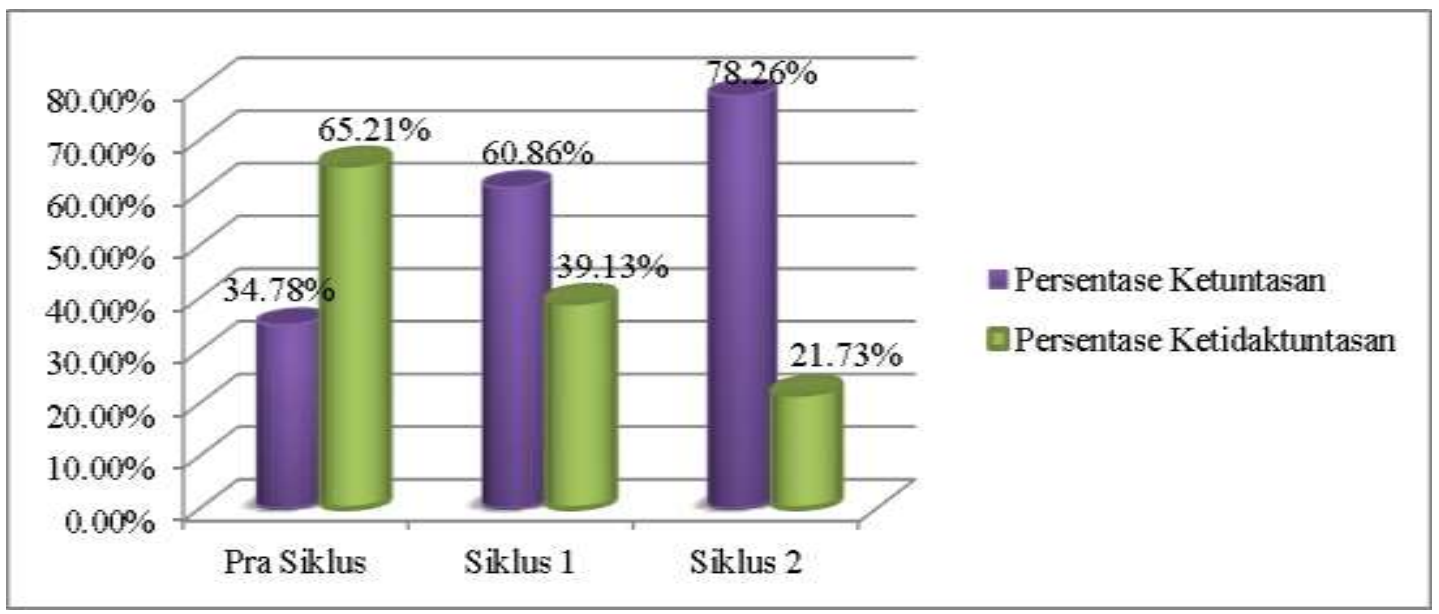

Gambar 3: Data Pengolahan Hasil Tes Tindakan Dari Pra Siklus Ke Siklus II 
Hasil belajar siswa turut meningkat seiring meningkatnya aktivitas belajar siswa dari siklus I ke siklus II. Dari gambar 3 tersebut menunjukkan bahwa model pembelajaran Numbered Head Together (NHT) dapat meningkatkan hasil belajar, aktivitas guru dan aktivitas siswa dalam proses pembelajaran. Sehingga siswa dapat mencapai kriteria ketuntasan minimal (KKM) dalam mata pelajaran matematika. Dengan hasil yang diperoleh siswa pada siklus II telah mencapi indikator keberhasilan penelitian tindakan kelas yang menjadi acuan dalam penelitian ini yaitu $70 \%$ sedangkan yang diperoleh $78,26 \%$. Artinya penelitian ini telah berhasil dilaksanakan sesuai dengan rencana pelaksanaan dengan dua siklus tindakan. Sehingga penelitian dicukupkan sampai pada siklus II, karena telah mencapai keberhasilan belajar siswa secara klasikal dan hasil belajar matematika kelas IV meningkat dengan penerapan model NHT. Adapun peningkatan hasil belajar dari pra siklus ke siklus I adalah 21,51\% sedangkan persentase peningkatan dari siklus I ke siklus II adalah $15,03 \%$ dan persentase peningkatan dari pra siklus ke siklus II adalah 39,78\%.

\section{PEMBAHASAN}

Penerapan model pembelajaran Numbered Head Together (NHT) dapat meningkatkan hasil belajar matematika kelas IV SDN 3 Tinanggea. Hal ini dapat dilihat dari terlaksananya rencana pelaksanaan pembelajaran yang dilakukan oleh guru dan aktivitas siswa selama proses pembelajaran dengan menggunakan model pembelajaran Numbered Head Together (NHT). Peningkatan ini disebabkan oleh: Guru menerapkan model pembelajaran NHT dengan cukup baik dan mulai menyadari bahwa model pembelajaran ini mampu mengubah kondisi pembelajaran dikelas menjadi lebih efektif dan menyenangkan. Selain itu NHT mampu meningkatkan kepercayaan diri siswa, memperbaiki tingkat kehadirannya dalam proses belajar mengajar, lebih mudah menerima orang lain, mengurangi prilaku yang mengganggu, mengurangi konflik antar pribadi, meningkatkan budi pekerti, kepekaan sosial dan toleransi, memperoleh pemahaman yang lebih mendalam, serta hasil belajar lebih baik. (Bakarudin, 2011).

Bertitik tolak pada uraian di atas maka aktivitas guru dan aktivitas siswa berdampak pada meningkatnya hasil belajar siswa. Dimana hasil belajar siswa dari pra siklus hasil persentase ketuntasan masih mencapai 34,78\% dengan nilai rata-rata 60,65. Pada siklus I hasil belajar siswa mencapai $60,86 \%$ dengan nilai rata-rata 73,70 dan pada siklus 2 presentase ketuntasan hasil belajar siswa mencapai $78,26 \%$ dengan nilai rata-rata 84,78 . Model NHT dapat meningkatkan efektivitas pembelajaran dan meningkatkan pencapaian indikator kompetensi. Selain itu, proses pembelajaran akan meningkat apabila model dan media yang kita gunakan relevan dengan materi yang diajarkan pada saat pembelajaran.

Hal ini diperkuat dengan penelitian yang dilakukan oleh Ridha Sulfiani. Pada penelitian ini hasil yang diperoleh pada setiap siklusnya memperoleh peningkatan yang cukup drastis baik aktivitas belajar siswa maupun aktivitas mengajar guru. Dimana aktivitas belajar siswa secara klasikal pada siklus I mencapai 64,95\%. Kemudian pada siklus II meningkat menjadi 90,50\% dengan kategori amat baik. Keterampilan guru juga mengalami peningkatan siklus I mencapai 50,33\% dengan kategori cukup dan pada siklus II meningkat menjadi 62,50\% dengan kategori baik. Kemudian model NHT dapat meningkatkan hasil belajar siswa, dimana pencapaian hasil belajar pada siklus I sebesar 44,82\% dan pada siklus II sebesar 79,31\%. (Ridha Sulfiani, 2016)

\section{SIMPULAN}

Dari hasil analisis dan pembahasan menunjukkan bahwa penerapan model pembelajaran Numbered Head Together (NHT) pada pembelajaran matematika, diketahui bahwa aktivitas guru dan aktivitas siswa mengalami peningkatan dari setiap siklus. Hal ini dapat dilihat dari persentase aktivitas guru dari siklus 1 ke siklus II yaitu $11,11 \%$ menjadi $3,71 \%$. Sedangkan persentase aktivitas siswa mengalami peningkatan dari siklus I ke siklus II yaitu $14,82 \%$ menjadi $7,41 \%$. Hasil belajar kognitif siswa mengalami peningkatan, yaitu dengan nilai rata-rata hasil belajar pra siklus sebesar 60,65 , 
siklus I sebesar 73,70 dan pada siklus II sebesar 84,78. Tingkat ketuntasan pada pra siklus adalah $34,78 \%$, pada siklus I menjadi 60,86\% dan pada siklus II menjadi 78,26\%. Adapun persentase peningkatan dari pra siklus ke siklus I adalah $21,51 \%$ sedangkan persentase peningkatan dari siklus I ke siklus II adalah 15,03\% dan persentase peningkatan dari pra siklus ke siklus II adalah 39,78\%. Hasil belajar meningkat karena dampak dari aktivitas guru dan siswa disetiap siklusnya. Dengan demikian model pembelajaran Numbered Head Together (NHT) dapat meningkatkan hasil belajar siswa kelas IV SDN 3 Tinanggea.Penerapan model Numbered Head Together (NHT) sebagai alternatif pengajaran bagi guru dalam meningkatkan hasil belajar siswa. Guru diharapkan mampu memotivasi siswa lebih aktif serta mampu menciptakan suasana kelas yang menyenangkan sehingga siswa merasa nyaman dan menjadi termotivasi untuk belajar.

\section{DAFTAR PUSTAKA}

Arikunto Suharsimi. 2006. Prosedur Penelitian Suatu Pendekatan Praktik (Jakarta: Rineka Cipta). 137

Aqib Zainal. 2013. Model-Model Media, dan Strategi Pembelajaran Kontekstual (Inovatif), (Bandung: Yrama Widya). 18-19.

Bakarudin, Mustafa, Yusnani. 2011. Number Heads Together Untuk Meningkatkan keaktifan dan Penguasaan Konsep Matematika, Jurnal PTK DBE3.Volume Khusus No. 1. 28

Daryanto \& M. Raharjo. 2012. Model Pembelajaran Inovatif, (Yogyakarta: Gava Media). 240

Dimyati \& Mudjiono. 2013. Belajar Dan Pembelajaran, (Jakarta: Rineka Cipta). 3

Ekawarna. 2009. Penelitian Tindakan Kelas (Jakarta: GP. Press). 5

Imas Kurniasih dan Berllin Sani. 2015. Ragam Pengembangan Model Pembelajaran (Untuk Peningkatan Prefesionalitas Guru), (Jakarta: Kata Pena). 29

Jumanta Hamdayama. 2014. Model Dan Metode Pembelajaran Kreatif Dan Berkarakter, (Bogor: Ghalia Indonesia). 177

Kawuwung Femmy. 2011."Profil Guru, Pemahaman Kooperatif NHT, Dan Kemampuan Berfikir Tingkat Tinggi Di SMP K abupaten Minahasa Utara”, El-Hayah, .Vol.1 No. 4. 157-158

Sulfiani Ridha. 2016. Penerapan Model Pembelajaran Kooperatif Tipe Numbered Head Together (NHT) Untuk Meningkatkan Hasil Belajar Kimia Siswa Kelas IX IPA I SMA Negeri 3 Watampone ( Studi Pada Materi Pokok Struktur Atom, Sistem Priodik Unsur dan Bentuk Molekul). Jurnal Chemica Vol. 17 No. 1. 5-6

Susanto Ahmad. 2013. Teori Belajar \& Pembelajaran di Sekolah Dasar, (Jakarta: Kencana). 83

Undang-Undang Republik Indonesia No. 20 Tahun 2003 Tentang Sistem Pendidikan Nasional (SISDIKNAS). (Bandung: Citra Umbara, 2003)

Warsono dan Hariyanto. 2012. Pembelajaran aktif, (Bandung: PT. Remaja Rosdakarya). 216-217 